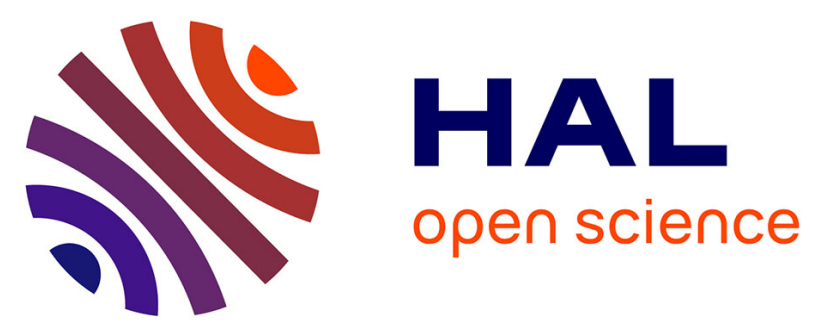

\title{
EGFR and KRAS mutation status in non-small-cell lung cancer occurring in HIV-infected patients
}

Perrine Créquit, Anne-Marie Ruppert, Nathalie Rozensztajn, Valérie

Gounant, T. Vieira, Virginie Poulot, Martine Antoine, Christos Chouaid, Marie Wislez, Jacques Cadranel, et al.

\section{To cite this version:}

Perrine Créquit, Anne-Marie Ruppert, Nathalie Rozensztajn, Valérie Gounant, T. Vieira, et al.. EGFR and KRAS mutation status in non-small-cell lung cancer occurring in HIV-infected patients. Lung Cancer, 2015, 96, pp.74-77. 10.1016/j.lungcan.2015.11.021 . hal-01244704

\section{HAL Id: hal-01244704 https://hal.sorbonne-universite.fr/hal-01244704}

Submitted on 16 Dec 2015

HAL is a multi-disciplinary open access archive for the deposit and dissemination of scientific research documents, whether they are published or not. The documents may come from teaching and research institutions in France or abroad, or from public or private research centers.
L'archive ouverte pluridisciplinaire HAL, est destinée au dépôt et à la diffusion de documents scientifiques de niveau recherche, publiés ou non, émanant des établissements d'enseignement et de recherche français ou étrangers, des laboratoires publics ou privés. 
EGFR and KRAS mutation status in non-small-cell lung cancer occurring in HIVinfected patients

Perrine Créquit ${ }^{1}$, Anne-Marie Ruppert ${ }^{1,2}$, Nathalie Rozensztajn ${ }^{1}$, Valérie Gounant ${ }^{1,2}$, T. Vieira $^{1,2}$, Virginie Poulot ${ }^{2,3}$, Martine Antoine ${ }^{2,4}$, Christos Chouaid ${ }^{5}$, Marie Wislez ${ }^{1,2}$, Jacques Cadranel $^{1,2}$, and Armelle Lavole ${ }^{1,2}$

\section{Affiliations:}

1- Service de Pneumologie, AP-HP, Hôpital Tenon, Paris, France

2- Sorbonne Universités, UPMC Univ. Paris 06, GRC-04, Théranoscan, Paris, France

3-Plateforme de Génomique des Tumeurs solides et Cytologie pathologiques, AP-HP, Hôpital Tenon, Paris, France

4- Service d'Anatomie pathologique, AP-HP, Hôpital Tenon, Paris, France

5- Service de Pneumologie, Centre Hospitalier Intercommunal, Créteil, France

Corresponding author: Armelle Lavolé, Service de Pneumologie, Hôpital Tenon, 4 rue de la Chine, F-75970 Paris cedex 20

Tel.: + 32(0)1 560175 12; email: armelle.lavole@tnn.aphp.fr 


\section{Highlights}

- 63 tumor samples were analyzed for EGFR and KRAS mutation out of 73 HIVNSCLC.

- EGFR mutations were identified in two patients (3.3\%).

- Proportion of KRAS mutations was $29 \%$ using the more sensitive molecular techniques.

- EGFR mutations exhibited lasting partial response to EGFR-tyrosine kinase inhibitors.

- KRAS mutation is of poor prognostic value. 


\section{ABSTRACT}

Non-small-cell lung cancer (NSCLC) is the most common non-acquired immune deficiency syndrome-related malignancy responsible for death. Mutational status is crucial for choosing treatment of advanced NSCLC, yet no data is available on the frequency of epidermal growth factor receptor $(E G F R)$ and Kirsten ras $(K R A S)$ mutations and their impact on NSCLC in human immunodeficiency virus (HIV)-infected patients (HIV-NSCLC).

All consecutive HIV-NSCLC patients diagnosed between June 1996 and August 2013 at two Paris university hospitals were reviewed, with tumor samples analyzed for EGFR and KRAS mutational status.

Overall, 63 tumor samples were analyzed out of 73 HIV-NSCLC cases, with $63 \%$ of advanced NSCLC. There were 60 non-squamous and nine squamous cell carcinomas, with EGFR and KRAS mutations identified in two (3.3\%) and seven (11.5\%) tumors, respectively. The proportion of KRAS mutations was $29 \%$ if solely the more sensitive molecular techniques were considered. The two patients with advanced adenocarcinoma harboring EGFR mutations exhibited lasting partial response to EGFR-tyrosine kinase inhibitors. Overall survival for patients with advanced NSCLC were $>30$ months for those with EGFR mutations, <3 months for $K R A S$ mutations $(\mathrm{n}=2)$, and the median was 9 months [4.1-14.3] for wild-type $(\mathrm{n}=34)$. In multivariate analysis, $K R A S$ mutation and $\mathrm{CD} 4<200$ cells $/ \mu \mathrm{L}$ were associated with poor prognosis (hazard ratio (HR): 24 [4.1-140.2], $\mathrm{p}=0.0004$; HR: 3.1 [1.3-7.5], p=0.01, respectively). 
EGFR mutation must be investigated in HIV-NSCLC cases due to its predictive and prognostic impact, whereas KRAS mutation is of poor prognostic value. Clinicians should search for drugs dedicated to this target population.

Key words: human immunodeficiency virus (HIV), non-small-cell lung cancer (NSCLC), epidermal growth factor receptor (EGFR) mutation, Kirsten Ras (KRAS) mutation 


\section{INTRODUCTION}

Recent studies have shown that the life expectancy of human immunodeficiency virus (HIV)-positive patients with controlled infection and high CD4 T-cell counts has dramatically increased since the development of highly active antiretroviral treatment (HAART). In industrialized countries, it can even be assumed to approach the life expectancy of the general population of the same age and gender [1]. Rates of mortality related to non-acquired immune deficiency syndrome-defining malignancy (NADM) are increasing [2]. Lung cancer (LC) is the most common NADM, with $90 \%$ of cases being specifically non-small cell lung cancer (NSCLC), and represents the leading cause of cancer-related death among people living with HIV [3].

The NSCLC risk has been estimated to be three times higher among HIV-infected individuals than within the general population [4]. Although largely attributed to heavy smoking [5], it is uncertain whether other co-factors contribute to this increased risk, such as low CD4 cell counts [6]. Theories attempting to explain the poorer prognosis of HIV patients with LC (HIV-LC) have not yet been resolved, particularly for those with controlled infection and high CD4 T-cell counts [6]. Moreover, a recent study demonstrated that LC-related mortality was higher among HIV-positive individuals after adjusting for age, gender, ethnicity, tumor node metastasis (TNM) stage, cancer treatment, and smoker status [7].

In the last decade, we have witnessed a major evolution in both molecular diagnostics and individualized therapy pertaining to the management of advanced NSCLC. With the 
identification of the epidermal growth factor receptor (EGFR) mutation and renewed interest in the Kirsten Ras $(K R A S)$ mutation, our understanding of the heterogeneity of NSCLC has been dramatically changed. No data is currently available, however, on the frequency of EGFR and KRAS mutations in HIV-NSCLC cases. A Japanese cohort study involving 43 HIV-NSCLC cases identified five patients harboring EGFR mutations out of a total of 14 available for examination from 1986 to 2013 [8]. Another cohort of 74 HIV-NSCLC patients in New York identified two patients harboring KRAS mutations out of seven available for examination [9]. Our study sought to estimate the frequency of $E G F R$ and $K R A S$ mutations in an HIV-NSCLC cohort and analyze the clinical characteristics and outcomes of these according to their mutational status and treatment. We also investigated the impact of patient characteristics and mutations on overall survival.

\section{MATERIELS AND METHODS}

\section{Patients}

All the consecutive HIV-infected patients with histologically-proven NSCLC diagnosed between June 1996 and August 2013 at two Paris university hospitals (France) were reviewed. For each patient, the following clinical and biological characteristics were collected: age, gender, smoker status, performance status (PS) at diagnosis, tumor histology according to the 2004 World Health Organization classification, clinical TNM stage as defined by the $7^{\text {th }}$ TNM classification, and LC treatment. We also recorded HIV characteristics at the time of cancer 
diagnosis, comprising HAART treatment, HIV-viral load, and median CD4 lymphocyte count. The patients were followed up until August 2014.

\section{EGFR and KRAS mutational status}

For each sample, the proportion of tumor cells in comparison with the total of non necrotic cells observed was assessed on the $3 \mu \mathrm{m}$ slide performed at the end of block sections and stained by hematoxylin-eosine-safran coloration (HES). At least three $10 \mu \mathrm{m}$-thick sections from paraffin blocks were prepared for each case, with deoxyribonucleic acid (DNA) extraction carried out by means of the QIAmp DNA mini-kit (Qiagen ${ }^{\circledR}$, Netherlands). From mid-2005 to mid-2010, molecular analyses were performed using direct DNA sequencing. From the middle of 2010, the following more sensitive molecular techniques were used: for $K R A S$, Taqman allelic discrimination of exon 2; for EGFR, Taqman allelic discrimination of exon 18, 20 and 21; for insertions/deletions of exons 19 and 20, fragment size separation. At least three polymerase chain reaction (PCR) amplification attempts were mandatory for each exon before the sample was considered to be not available. Mutations were confirmed by sequencing analysis using a second independent PCR.

\section{Statistical analysis}

Univariate analyses were performed by means of the Mann-Whitney U-test for continuous variables, and Fisher's exact test for categorical data. Cumulative long-term survival curves 
were analysed by means of the Kaplan-Meier method. Impact on survival was quantified using Cox regression models and hazard ratios (HR), with 95\% confidence interval (CI) applied. Variables with a $p$ value $<0.2$ in univariate analysis were introduced into multivariate analyses. The threshold value for statistical significance was set at 0.05 . The statistical analyses were conducted using SAS 9.3 software (SAS Institute, Cary, North Carolina, USA).

\section{RESULTS}

In total, 73 HIV-NSCLC cases were identified and 63 (86.3\%) EGFR/KRAS mutational status could be obtained. There was $40 \%$ of LC specimens examined at the time of diagnosis. No tissue samples were available for six patients (8.2\%) and a technical failure was reported for four $(5.5 \%)$. The median proportion of tumor cells in the samples was $40 \%$ (interquartile range [IQR]: 20\%-70\%). Two-thirds of the tumoral samples were analyzed by direct DNA sequencing. NSCLC was primarily diagnosed in small samples $(n=44,70 \%)$ and some through surgical biopsy $(\mathrm{n}=19,30 \%)$.

\section{Description of the overall population}

There were no differences observed in terms of patient, tumor, or HIV characteristics between the patients analyzed $(n=63)$ and those not analyzed $(n=10)$ for mutational status. The patient characteristics have been presented in Table 1. At the time of NSCLC diagnosis, 46 patients (63\%) were already receiving HAART, which was initiated for the first time in 10 others. By the end point of the study, 59 patients $(80.8 \%)$ had died due to NSCLC. 


\section{Description of EGFR mutation patients}

Two patients (3.3\%) with advanced-stage adenocarcinoma presented EGFR mutations consisting of exon 19 deletion detected at the time of diagnosis (Table 1). These patients received erlotinib as second-line treatment and exhibited response for 14 and 15 months, respectively. Both patients presented cutaneous acneiform rash, which prompted stopping erlotinib in one. The HAART used at the time of erlotinib treatment consisted of ritonavir and atazanavir for one and abacavir+lamivudine and atazanavir for the other. Drug interference between erlotinib and ritonavir was the likely cause for the limitant skin toxicity observed. The patient in whom erlotinib was stopped was re-challenged by gefitinib several months later, exhibiting good tolerance and a partial response over 14 months. He then presented slow disease progression, which led to gefitinib being continued as a result of his refusal of chemotherapy. After 21 months of gefitinib treatment, bronchial biopsies revealed the persistence of exon 19 deletion, as well as the occurrence of a T790M mutation.

\section{Description of KRAS mutation patients}

KRAS mutations were detected in the tissue samples of seven patients (11.5\%) (Table 1), with $83 \%$ detected in samples stored for more than five years and $71 \%$ found in surgical samples. The majority of the patients displaying $K R A S$ mutation were Stage I-IIIA (71.4\%), contrary to the global cohort $(\mathrm{p}=0.03)$. 


\section{Impact of clinical characteristics and mutational status on overall survival}

Given the fact that mutational status has no real impact on treatment choice for Stage I-IIIA, we focused our analysis on patients with advanced NSCLC. In univariate analysis, the variables significantly associated with an overall survival benefit were as follows: smoking cessation (HR: 0.5 [0.2-1.2], p=0.13), highly-active antiretroviral treatment (HR: 0.5 [0.31.1], $\mathrm{p}=0.08$ ) and $E G F R$ mutation (HR: 0.1 [0.02-1.1], p=0.06). A CD4 count $<200$ cells $/ \mu \mathrm{L}$ and KRAS mutation were associated with poor prognosis (HR: 3 [1.4-6.6], $\mathrm{p}=0.01$; HR: 16.5 [3-92.1], $\mathrm{p}=0.003$, respectively). In multivariate analyses, the two factors significantly associated with poor overall survival were KRAS mutation (HR: 24 [4.1-140], p=0.0004) and CD4 count $<200$ cells/ $\mu \mathrm{L}$ (HR: 3.1 [1.3-7.5], $\mathrm{p}=0.01$ ). There was also a favorable trend spotted for EGFR mutations (HR: 0.2 [0.02-1.9], p=0.2).

\section{DISCUSSION}

This manuscript presents the largest study of the epidemiology, clinical characteristics, and prognostic impact of HIV-NSCLC patients according to their EGFR and KRAS status.

The incidence of EGFR mutation was $3.3 \%$ in this HIV-NSCLC cohort. This low frequency may be explained by the observation that our HIV-NSCLC patients were primarily male, Caucasian, and current heavy smokers. The EGFR mutation incidence was, in fact, 5 to 
$10 \%$ for the Caucasian population, and $4.2 \%$ for smoker patients [10]. This incidence decrease for current smokers compared to former smokers was also echoed by an inverse relationship between the incidence of EGFR mutations and number of pack-years of cigarette smoking [11]. Similar to non-HIV patients, EGFR mutation appeared to constitute a favorable prognostic factor of survival, being associated with longer responses to EGFR-TKI treatment. These findings are consistent with those reported by other studies (Table 2) [12, 13]. Potential drug-drug interactions between HAART and oral therapeutics have been seen to lead to cumulative toxicity. For instance, protease inhibitors, especially ritonavir, must be stopped when concomitantly prescribed with EGFR-TKI.

The frequency of KRAS mutations was $11.5 \%$ in our cohort, clearly lower than the expected incidence for such population. However, $71 \%$ of the mutations were identified on surgical samples, and $70 \%$ by direct DNA sequencing from small samples. Direct sequencing has been established to be less sensitive than alternative testing [14]. Moreover, most of the samples analyzed retrospectively were stored for more than five years which may result in DNA oxidation and fragmentation [14]. If only the most sensitive techniques were considered, the frequency of KRAS mutations did, in fact, increase to $29 \%$. Even if we had underestimated KRAS mutation incidence, however, its negative prognostic factor was still clearly evident. Indeed, KRAS mutation confers poor prognosis with intrinsic resistance to cytotoxic chemotherapeutic drugs. Some upcoming investigational drugs are being studied such as CDK-4/6 inhibitor (Abemaciclib) or selective MEK inhibitor (Selumetinib).

\section{CONCLUSIONS}

Although there were few HIV-NSCLC patients with EGFR mutations, we conclude that it is 
primordial to search for this mutation in this particular population, owing to its dramatic impact on EGFR-TKI response, and thus overall survival. Furthermore, identifying KRAS mutations in HIV-NSCLC cases could become more crucial in the future for selecting heavysmoker patients with poor prognosis who could benefit from immune checkpoint inhibitors [15]. Finally, smoking cessation must be incorporated as routine into the care of HIV-positive smokers.

\section{Conflict of interest statement:}

None declared. 


\section{References}

1. Collaboration of Observational HIVEREiE, Lewden C, Bouteloup V, De Wit S, Sabin C, Mocroft A, Wasmuth JC, van Sighem A, Kirk O, Obel N, Panos G, Ghosn J, Dabis F, Mary-Krause M, Leport C, Perez-Hoyos S, Sobrino-Vegas P, Stephan C, Castagna A, Antinori A, d'Arminio Monforte A, Torti C, Mussini C, Isern V, Calmy A, Teira R, Egger M, Grarup J, Chêne G. All-cause mortality in treated HIV-infected adults with CD4 $\geq 500 / \mathrm{mm} 3$ compared with the general population: evidence from a large European observational cohort collaboration. International Journal of Epidemiology 2012;41: 433-445.

2. Smith CJ, Ryom L, Weber R, Morlat P, Pradier C, Reiss P, Kowalska JD, de Wit S, Law M, el Sadr W, Kirk O, Friis-Moller N, Monforte AdA, Phillips AN, Sabin CA, Lundgren JD, Group DADS. Trends in underlying causes of death in people with HIV from 1999 to 2011 (D:A:D): a multicohort collaboration. Lancet (London, England) 2014;384: 241-248.

3. Morlat P, Roussillon C, Henard S, Salmon D, Bonnet F, Cacoub P, Georget A, Aouba A, Rosenthal E, May T, Chauveau M, Diallo B, Costagliola D, Chene G, Group AEMS. Causes of death among HIV-infected patients in France in 2010 (national survey): trends since 2000. AIDS (London, England) 2014;28: 1181-1191.

4. Shiels MS, Cole SR, Kirk GD, Poole C. A meta-analysis of the incidence of nonAIDS cancers in HIV-infected individuals. Journal of Acquired Immune Deficiency Syndromes (1999) 2009;52: 611-622.

5. Helleberg M, Gerstoft J, Afzal S, Kronborg G, Larsen CS, Pedersen C, Bojesen SE, Nordestgaard BG, Obel N. Risk of cancer among HIV-infected individuals compared to the background population: impact of smoking and HIV. AIDS (London, England) 2014;28: 1499-1508.

6. Mani D, Haigentz M, Aboulafia DM. Lung cancer in HIV Infection. Clinical Lung Cancer 2012;13: 6-13.

7. Marcus JL, Chao C, Leyden WA, Xu L, Yu J, Horberg MA, Klein D, Towner WJ, Quesenberry CP, Abrams DI, Silverberg MJ. Survival Among HIV-Infected and HIVUninfected Individuals with Common Non-AIDS-Defining Cancers. Cancer Epidemiology, Biomarkers \& Prevention: A Publication of the American Association for Cancer Research, Cosponsored by the American Society of Preventive Oncology 2015.

8. Okuma Y, Tanuma J, Kamiryo H, Kojima Y, Yotsumoto M, Ajisawa A, Uehira T, Nagai H, Takeda Y, Setoguchi Y, Okada S. A multi-institutional study of clinicopathological features and molecular epidemiology of epidermal growth factor receptor mutations in lung cancer patients living with human immunodeficiency virus infection. Journal of Cancer Research and Clinical Oncology 2015;141: 1669-1678.

9. Levy B, Chintapatla R, Suarez J, Connery CP, Bhora FY, Evans A, Choi W, Rohs N, 
Becker DJ. HIV-associated lung cancer in New York City. In: Journal of Clinical Oncology: Official Journal of the American Society of Clinical Oncology, 2013:15SUPPL.11.

10. Barlesi F, Blons H, Beau-Faller M, et al. Biomarkers (BM) France: Results of routine EGFR, HER2, KRAS, BRAF, PI3KCA mutations detection and EML4-ALK gene fusion assessment on the first 10,000 non-small cell lung cancer (NSCLC) patients (pts). In: J Clin Oncol, 2013:abstract-8000.

11. D'Angelo SP, Pietanza MC, Johnson ML, Riely GJ, Miller VA, Sima CS, Zakowski MF, Rusch VW, Ladanyi M, Kris MG. Incidence of EGFR exon 19 deletions and L858R in tumor specimens from men and cigarette smokers with lung adenocarcinomas. Journal of Clinical Oncology: Official Journal of the American Society of Clinical Oncology 2011;29: 2066-2070.

12. Erickson TM, Koeppe JR, Miller YE, Stuart RW, Camidge DR. Bronchioloalveolar carcinoma presenting as chronic progressive pulmonary infiltrates in a woman with HIV: a diagnosis worth making. Journal of Thoracic Oncology: Official Publication of the International Association for the Study of Lung Cancer 2008;3: 1353-1355.

13. Okuma Y, Hosomi Y, Imamura A. Lung cancer patients harboring epidermal growth factor receptor mutation among those infected by human immunodeficiency virus. OncoTargets and Therapy 2015;8: 111-115.

14. Beau-Faller M, Degeorges A, Rolland E, Mounawar M, Antoine M, Poulot V, Mauguen A, Barbu V, Coulet F, Prétet J-L, Bièche I, Blons H, Boyer J-C, Buisine MP, de Fraipont F, Lizard S, Olschwang S, Saulnier P, Prunier-Mirebeau D, Richard N, Danel C, Brambilla E, Chouaid C, Zalcman G, Hainaut P, Michiels S, Cadranel J. Cross-validation study for epidermal growth factor receptor and KRAS mutation detection in 74 blinded non-small cell lung carcinoma samples: a total of 5550 exons sequenced by 15 molecular French laboratories (evaluation of the EGFR mutation status for the administration of EGFR-TKIs in non-small cell lung carcinoma [ERMETIC] project--part 1). Journal of Thoracic Oncology: Official Publication of the International Association for the Study of Lung Cancer 2011;6: 1006-1015.

15. Corthay A. Does the immune system naturally protect against cancer? Frontiers in Immunology 2014;5: 197. 
Table I: Patient characteristics according to mutational status

\begin{tabular}{|c|c|c|c|c|}
\hline Characteristics & $\begin{array}{c}\text { All } \\
\mathrm{N}=73\end{array}$ & $\begin{array}{c}\text { EGFR/KRAS } \\
\text { Wild-type } \\
\text { N=54 }\end{array}$ & $\begin{array}{c}\text { EGFR mutation } \\
\qquad \begin{array}{c}\mathrm{N}=2 \\
\end{array}\end{array}$ & $\begin{array}{c}\begin{array}{c}\text { KRAS mutation } \\
\mathrm{N}=7\end{array} \\
\end{array}$ \\
\hline Age (years) ${ }^{\circ}$ & $51[46-57]$ & $52[46-58]$ & 49,60 & $50[42-53]$ \\
\hline $\begin{array}{l}\text { Gender } * \\
\text { Men } \\
\text { Women }\end{array}$ & $\begin{array}{l}62(84.9) \\
11(15.1)\end{array}$ & $\begin{array}{c}45(83.3) \\
9(16.7)\end{array}$ & $\begin{array}{c}2(100) \\
0(0)\end{array}$ & $\begin{array}{c}7(100) \\
0(0)\end{array}$ \\
\hline $\begin{array}{l}\text { Ethnicity } * \\
\text { Caucasian } \\
\text { Others } \\
\end{array}$ & $\begin{array}{c}70(95.9) \\
3(4.1) \\
\end{array}$ & $\begin{array}{c}53(98.1) \\
1(1.9) \\
\end{array}$ & $\begin{array}{c}2(100) \\
0(0)\end{array}$ & $\begin{array}{c}7(100) \\
0(0)\end{array}$ \\
\hline $\begin{array}{l}\text { Smoker status * } \\
\text { Never } \\
\text { Former } \\
\text { Current }\end{array}$ & $\begin{array}{c}0(0) \\
14(19.2) \\
59(80.8)\end{array}$ & $\begin{array}{c}0(0) \\
10(18.5) \\
44(81.5)\end{array}$ & $\begin{array}{c}0(0) \\
2(100) \\
0(0)\end{array}$ & $\begin{array}{c}0(0) \\
0(0) \\
7(100)\end{array}$ \\
\hline Number of PY $¥$ & $35[25-47]$ & $35[25-50]$ & 21,41 & $40[33-45]$ \\
\hline $\begin{array}{l}\text { Histology } * \$ \\
\text { Adenocarcinoma/Large cell } \\
\text { Squamous cell } \\
\text { Other }\end{array}$ & $\begin{array}{c}60(82.2) \\
9(12.3) \\
4(5.5) \\
\end{array}$ & $\begin{array}{c}42(77.8) \\
9(16.7) \\
3(5.5)\end{array}$ & $\begin{array}{l}2(100) \\
0(0) \\
0(0)\end{array}$ & $\begin{array}{l}7(100) \\
0(0) \\
0(0)\end{array}$ \\
\hline $\begin{array}{c}\text { Disease stage } * \\
\text { I-IIIA } \\
\text { IIIB-IV \& }\end{array}$ & $\begin{array}{l}27(37) \\
46(63)\end{array}$ & $\begin{array}{l}20(37) \\
34(63)\end{array}$ & $\begin{array}{c}0(0) \\
2(100)\end{array}$ & $\begin{array}{l}5(71.4) \\
2(28.6)\end{array}$ \\
\hline $\begin{array}{l}\text { Performance status * } \\
\quad 0-1 \\
\quad>=2\end{array}$ & $\begin{array}{l}56(80) \\
14(20)\end{array}$ & $\begin{array}{l}44(81.5) \\
10(18.5)\end{array}$ & $\begin{array}{l}1(50) \\
1(50)\end{array}$ & $\begin{array}{l}6(85.7) \\
1(14.3)\end{array}$ \\
\hline 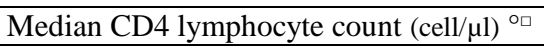 & $450[283-657]$ & $460[250-700]$ & 300,480 & $419[380-561]$ \\
\hline CD4 <200 (cell/ $/ \mu 1) * \square$ & $14(19.2)$ & $12(22.2)$ & $0(0)$ & $0(0)$ \\
\hline Viral Load undetectable $* \square$ & $40(54.8)$ & $30(55.6)$ & $0(0)$ & $6(85.7)$ \\
\hline HAART $*$ & $56(76.7)$ & $40(74.1)$ & $2(100)$ & $7(100)$ \\
\hline HIV performed at LC diagnosis $* ¥$ & $10(13.9)$ & $7(13.2)$ & $1(50)$ & $0(0)$ \\
\hline $\begin{array}{l}\text { Status } * \\
\text { Alive } \\
\text { Dead }\end{array}$ & $\begin{array}{l}14(19.2) \\
59(80.8)\end{array}$ & $\begin{array}{l}11(20.4) \\
43(79.6)\end{array}$ & $\begin{array}{l}1(50) \\
1(50)\end{array}$ & $\begin{array}{l}2(28.6) \\
5(71.4)\end{array}$ \\
\hline Overall survival (months) $^{\circ}$ & $13.2[5.1-25]$ & $12.7[4.7-20.2]$ & $29.7 ; 75.3$ & $34.3[2.8-110.6]$ \\
\hline Stage I-IIIA (months) ${ }^{\circ}$ & $30.4[10.8-51.1]$ & $27.3[8.6-37]$ & NA & $51.1[34.3-110.6]$ \\
\hline Stage IIIB-IV (months) ${ }^{\circ}$ & $8.9[4.1-14.4]$ & $8.9[4.1-14.3]$ & $29.7 ; 75.3$ & $0.8 ; 2.8$ \\
\hline
\end{tabular}

EGFR: epidermal growth factor receptor; KRAS: Kirsten Ras; PY: (cigarette) pack years; CD4: cluster of differentiation 4; HAART: highly-active antiretroviral treatment; HIV: human immunodeficiency virus. $\$_{\text {including } 3} 3$ patients stage IIIB with surgical treatment, ${ }^{*}$ advanced disease (stage IIIB unsuitable for radical radiotherapy or surgery and stage IV), ${ }^{\circ}$ : median [interquartile range, IQR], $*: \mathrm{n}(\%),{ }^{*}: 1$ missing data, ${ }^{\square}: 3$ missing data, ${ }^{\$}: 4$ missing data for all patients 
Table 2: HIV patients with lung cancer harboring EGFR mutations from the literature and our study

\begin{tabular}{|c|c|c|c|c|c|c|c|c|c|c|c|c|c|c|c|}
\hline Author & Age & Gender & Smoking & PS & $\begin{array}{c}\text { Inaugural } \\
\text { HIV }\end{array}$ & HAART & Histology & Stage & $\begin{array}{c}\text { TKI } \\
\text { treatment } \\
\text { line }\end{array}$ & $\begin{array}{c}\text { EGFR } \\
\text { mutation }\end{array}$ & TKI & $\begin{array}{l}\text { Response } \\
\text { with TKI }\end{array}$ & $\begin{array}{l}\text { Response } \\
\text { duration } \\
\text { (months) }\end{array}$ & $\begin{array}{c}\text { TKI } \\
\text { toxicities }\end{array}$ & $\begin{array}{c}\text { Overall } \\
\text { survival } \\
\text { (months) }\end{array}$ \\
\hline Erickson & 52 & $\mathrm{~F}$ & $<1 \mathrm{PY}$ & - & No & Yes & BAC & IV & First & Exon 19 & Erlo & Response & +14 & $\begin{array}{c}\text { Mild } \\
\text { acneiform } \\
\text { rash }\end{array}$ & - \\
\hline Okuma & 67 & M & $\begin{array}{l}\text { Heavy } \\
\text { smoker }\end{array}$ & $\begin{array}{c}\text { Good } \\
\text { PS }\end{array}$ & No & Yes & Adeno & IIIB & Second & Exon 19 & Erlo & $\begin{array}{c}\text { Partial } \\
\text { response }\end{array}$ & 9.7 & $\begin{array}{c}\text { Mild } \\
\text { acneiform } \\
\text { rash }\end{array}$ & 39 \\
\hline Okuma & 59 & $\mathrm{M}$ & $\begin{array}{l}\text { Light } \\
\text { smoker }\end{array}$ & $\begin{array}{l}\text { Poor } \\
\text { PS }\end{array}$ & No & Yes & Adeno & IIIA & First & Exon 21 & Gef & $\begin{array}{l}\text { Partial } \\
\text { response }\end{array}$ & 22.1 & $\begin{array}{c}\text { Mild } \\
\text { acneiform } \\
\text { rash }\end{array}$ & \\
\hline $\begin{array}{l}\text { Our } \\
\text { cohort }\end{array}$ & 61 & $\mathrm{M}$ & $41 \mathrm{PY}$ & PS 0 & Yes & Yes & Adeno & IV & Second & Exon 19 & $\begin{array}{l}\text { Erlo } \\
\text { then } \\
\text { Gef }\end{array}$ & $\begin{array}{l}\text { Partial } \\
\text { response }\end{array}$ & $\begin{array}{l}15 \\
14\end{array}$ & $\begin{array}{c}\text { Severe } \\
\text { acneiform } \\
\text { rash }\end{array}$ & $\begin{array}{c}\text { Alive } \\
\text { (75.3 months } \\
\text { of follow-up) }\end{array}$ \\
\hline $\begin{array}{l}\text { Our } \\
\text { cohort }\end{array}$ & 49 & $\mathrm{M}$ & $21 \mathrm{PY}$ & PS 2 & No & Yes & Adeno & IV & Second & Exon 19 & Erlo & $\begin{array}{c}\text { Partial } \\
\text { response }\end{array}$ & 14 & $\begin{array}{c}\text { Mild } \\
\text { acneiform } \\
\text { rash }\end{array}$ & 30 \\
\hline
\end{tabular}

EGFR: epidermal growth factor receptor; HIV: human immunodeficiency virus; HAART: highly-active antiretroviral treatment; PS: performance status, TKI: tyrosine kinase inhibitor, PY: pack-year, BAC: bronchioloalveolar carcinoma; adeno: adenocarcinoma; Erlo: erlotinib; Gef: gefitinib 